\title{
Kardiyopulmoner Bypass Esnasında Antikoagülan Kullanımı Mikrotrombüs Oluşumunu Tam Olarak Engelliyor mu?
}

\section{Does the Use of Anticoagulants During Cardiopulmonary Bypass Prevent Microthrombosis Formation Completely?}

\author{
Veli Eşref KARASU ${ }^{1}$, Erdinç EROĞLU ${ }^{2}$, Alptekin YASIM ${ }^{3}$, Metin KILINÇ4, \\ Mehmet ACIPAYAM ${ }^{5}$, Aydemir KOÇARSLAN ${ }^{2}$, Mehmet KİRIŞCI் ${ }^{2}$ \\ ${ }^{1}$ Uzman Dr. Kahramanmaraş Sütçü İmam Üniversitesi Tip Fakültesi Kalp ve Damar Cerrahisi AD, KAHRAMANMARAŞ
${ }^{2}$ Yrd. Doç. Dr. Kahramanmaraş Sütçü İmam Üniversitesi Tip Fakültesi Kalp ve Damar Cerrahisi AD, KAHRAMANMARAŞ
${ }^{3}$ Prof. Dr. Kahramanmaraş Sütçü İmam Üniversitesi Tip Fakültesi Kalp ve Damar Cerrahisi AD, KAHRAMANMARAŞ
${ }^{4}$ Prof. Dr. Kahramanmaraş Sütçümam Üniversitesi Tip Fakültesi Tibbi Biyokimya AD, KAHRAMANMARAŞ
${ }^{5}$ Doç. Dr. Kahramanmaraş Sütçü İmam Üniversitesi Tip Fakültesi Kalp ve Damar Cerrahisi AD, KAHRAMANMARAŞ
}

Özet

Amaç: Bu çalışmada, kardiyopulmoner bypass esnasında heparin kullanımının mikrotrombüs oluşumunu tam olarak engelleyip engellemediği incelenmiştir.

Materyal ve Metod: Açık kalp cerrahisi yapılan 42 hastada anestezi indüksiyonu öncesi, kardiyopulmoner bypass (KPB) başladıktan yarım saat sonra, sternum kapatıldıktan sonra ve postoperatif 1 . günde faktör II, V, VII, X, antitrombin-III, protein C, protein S, fibrinojen, d-dimer, PT, aPTT ve hemogram için kan örnekleri alınarak koagulasyon sistemi değerlendirildi. Ayrıca karaciğer ve böbrek fonksiyonları ile nörokognitif fonksiyonlar değerlendirildi.

Bulgular: FII, FV, FVII, FX, AT III ve protein C değerleri KPB esnasında preoperatif değerine göre anlamlı olarak düşmekte, daha sonra yavaş yavaş yükselmekteydi. Protein S değeri ise KPB esnasında anlamlı olarak yükselmekte ve sonra preoperetif değerlerine inmekteydi. Fibrinojen seviyeleri dalgalı olarak seyrederken D dimer, PT ve aPTT değerleri KPB esnasında yükselmekteydi. Hemoglobin, hematokrit ve trombosit değerleri de KPB esnasında düşmekte, sonra yavaş yavaş yükselmekteydi. Hastalarda belirgin bir böbrek veya karaciğer fonksiyon bozukluğu ve nörokognitif fonksiyonlarda bozukluk saptanmadi.

Sonuç: KPB esnasında koagulasyon faktörlerinin azalmakta ve ardından yükselmesinin hemodilüsyona bağlı olabileceği düşünülebilir. Ancak D dimer seviyelerindeki artış, KPB esnasında bir trombüs oluşumu meydana geldiğini göstermektedir. Ancak bu trombüs oluşumu klinik olarak anlamlı değildir.

Anahtar Kelimeler: Kardiyopulmoner bypass, koagulasyon, mikrotrombosis

\section{GíRIŞ}

KPB kullanılarak yapılan açı kalp cerrahisi esnasında pek çok organ ve dokuda geçici fonksiyon bozukluğu oluşabilmektedir. Bu disfonksiyon genellikle kanın yabancı yüzeylere teması sonucu oluşan sistemik inflamatuar cevaba bağlı oluşmaktadır. Bu yabancı yüzey

\section{Abstract}

Objective: In this study, it was aimed to investigate whether the use of anticoagulants during cardiopulmonary bypass prevented microthrombosis formation.

Materials and Methods: The coagulation systems of 42 patients undergoing open heart surgery were evaluated by collecting blood specimens for factor (F) II, V, VII, and X, antithrombin-III (ATIII), protein C, protein S, fibrinogen, D-dimer, PT, aPTT and complete blood count investigation before induction of anesthesia, half an hour after start of CBP, following sternum closure and on postoperative day 1. Liver, kidney and neurocognitive functions were also evaluated.

Results: FII, FV, FVII, FX, AT-III and protein C values decreased significantly during CBP compared to preoperative values, and then gradually increased. Protein $S$ values increased significantly during CBP and subsequently decreased to preoperative levels. Fibrinogen levels fluctuated, while D-dimer, PT ve aPTT increased during CBP. Hemoglobin, hematocrit and platelet values also decreased during CBP, and then rose gradually. No significant kidney, liver or neurocognitive function impairment was determined.

Conclusion: Coagulation factors decreasing during CBP and then rising may be related to hemodilution. However, the increase in D-dimer shows that thrombus formation occurs during CBP, although this is not clinically significant.

Key Words: Cardiovascular bypass surgery; Coagulation; Microtrombosis.

Bu makale KSÜ Tip Fakültesinde yapılan 10146790 no.lu tezden üretilmiş ve KSÜ BAP tarafından desteklenmiştir (Proje No: 2016/5-65D).

\begin{tabular}{|c|c|c|}
\hline İletişim: & $\begin{array}{l}\text { Dr. Erdinç Eroğlu, KSÜ Tip Fakültesi Kalp ve Damar } \\
\text { Cerrahisi AD, Kahramanmaraş }\end{array}$ & 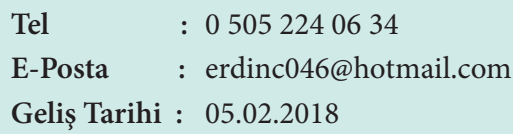 \\
\hline DOI: & 10.17517/ksutfd.390565 & Kabul Tarihi : 21.02 .2018 \\
\hline
\end{tabular}


Tablo 1: Çalışmaya alınan hastaların demografik, klinik ve cerrahi verileri

\begin{tabular}{|c|c|c|}
\hline & $\mathrm{N}$ & $\%$ \\
\hline $\begin{array}{l}\text { Cinsiyet durumu } \\
\text { Kadin } \\
\text { Erkek } \\
\text { Toplam }\end{array}$ & $\begin{array}{l}23 \\
19 \\
42 \\
\end{array}$ & $\begin{array}{c}54.8 \\
45.2 \\
100.0\end{array}$ \\
\hline & Ortalama \pm SS & Minimum-Maksimum \\
\hline Yaş (yıl) & $57.33 \pm 14.14$ & $18-75$ \\
\hline KPB süresi (dakika) & $78.04 \pm 31.85$ & $26-190$ \\
\hline Kros Klemp Süresi (dakika) & $44.30 \pm 23.87$ & $6-120$ \\
\hline Yoğun Bakımda Olan Drenajı (ml) & $465.47 \pm 238.00$ & $150-1000$ \\
\hline Kullanılan TDP sayısı (mL/kg) & $3.88 \pm 2.76$ & $0-15$ \\
\hline Kullanılan ES sayısı (mL/kg) & $2.52 \pm 1.65$ & $0-6$ \\
\hline Yoğun Bakım Süresi (gün) & $2.66 \pm 1.09$ & $1-5$ \\
\hline Postoperatif Kalış Süresi (gün) & $6.83 \pm 1.59$ & $3-14$ \\
\hline Yapılan Kardiyak Cerrahi & & \\
\hline $\mathrm{KABG}+\mathrm{Lima}$ & & 15 \\
\hline KABG & & 13 \\
\hline MVR & & 5 \\
\hline AVR & & 4 \\
\hline $\mathrm{MVR}+\mathrm{AVR}$ & & 2 \\
\hline BENTAL & & 1 \\
\hline $\mathrm{KABG}+\mathrm{AVR}$ & & 1 \\
\hline ASD & & 1 \\
\hline
\end{tabular}

${ }^{\star}$ SS: Standart sapma, KPB: Kardiyo-Pulmoner Baypass, TDP: Taze donmuş plazma, ES: Eritrosit süspansiyonu, KABG: Koroner arter bypass greftlemesi, MVR: Mitral kapak replasmanı, ASD: Atrial septal defekt, AVR: Aort kapak replasmanı.

mikrosirkulasyonda fibrin oluşumunun tamamen inhibe edilemeyerek KPB ile ilişkili koagulasyona yol açabileceği bildirilmiştir $(1,2) \quad$ Bu koagulasyonun sonucu oluşan 40 mikronun altındaki trombüsler vücudun çeşitli yerlerinde kalınlığ 1 8-10 mikron olan damarları tıkayarak kalp, akciğer, böbrek, santral sinir sistemi, pankreas ve karaciğer başta olmak üzere tüm organlarda geçici fonksiyonel bozukluklara sebep olabilir. Daha önce bazı olgularda KPB sonrası \% 60'a varan, 1 yıla dek uzayan ve ancak nörofizyolojik testlerle saptanabilen nörolojik defisitler bildirilmiştir (3). Bu nörolojik defisitlerin etiyolojisinde intraoperatif mikro veya makro emboliler sonucu oluşan nöronal hipoksi ve iskeminin rolü olduğu ifade edilmiştir (4). Yine KPB sonrasında oluşan geçici karaciğer ve böbrek fonksiyon bozukluğunun iskemiye bağlı olduğu bilinmektedir. Acaba bu iskemi KPB esnasında görülebilen kan basıncı düşüklügüne veya hemodilüsyona $\mathrm{m} ı$ bağlıdır, yoksa bu organlarda oluşan mikroemboliler mi bu tabloyu oluşturmaktadır?

Bir diğer soru oluşan mikroembolilerin hava veya partiküllere mi bağll, yoksa trombüs formasyonuna mı bağlı olduğudur? Eğer heparin KPB esnasında trombüs oluşumunu tam olarak engelleyemiyorsa o zaman KPB esnasinda ve sonrasinda koagulasyon parametrelerinin ölçümü bize bir fikir verebilir. Eğer bir trombüs oluşumu varsa öncelikle koagulasyon faktörlerinin plazma düzeylerinde azalış ve fibrin yıkım ürünlerinin miktarında bir artış beklenir.

$\mathrm{Bu}$ amaçla biz KPB esnasında ve sonrasında plazmadaki koagulasyon parametrelerinin düzeylerine bakarak indirekt olarak heparin kullanımına rağmen trombüs oluşup oluşmadığını araştırmayı planladık. Ayrıca karaciğer, böbrek ve nörokognitif fonksiyonlara bakarak bu durumu organ düzeyinde incelemeye çalıştık.

\section{GEREÇ VE YÖNTEM}

$\mathrm{Bu}$ çalışma prospektif kesitsel olarak tasarlandı. Çalışma 01.05.2016 - 10.06.2016 tarihleri arasında Kahramanmaraş Sütçü İmam Üniversitesi Tip Fakültesi Hastanesi Kalp Damar Cerrahi Kliniğinde yapıldı. Açık kalp cerrahisi yapilan toplam 42 hasta çalışmaya dahil edildi. Hastalara çalışma hakkında bilgi verildikten sonra yazılı onamları alındı. Araştırma için Üniversite Etik Kurulundan etik onay ve yasal izni alındı. Bu çalışmada, araştırma düzeni gerektiren Helsinki Deklarasyonu’na uyuldu.

Antikoagülan ve antiagregan ilaç alan hastalar, kanama prhtılaşma bozukluğu olan, böbrek fonksiyon bozukluğu, karaciğer fonksiyon bozukluğu, nörobilişsel fonksiyon bozukluğu olan ve ameliyat sonrası revizyona 
Tablo 2: Çalışmaya alınan hastaların koagülasyon parametreleri

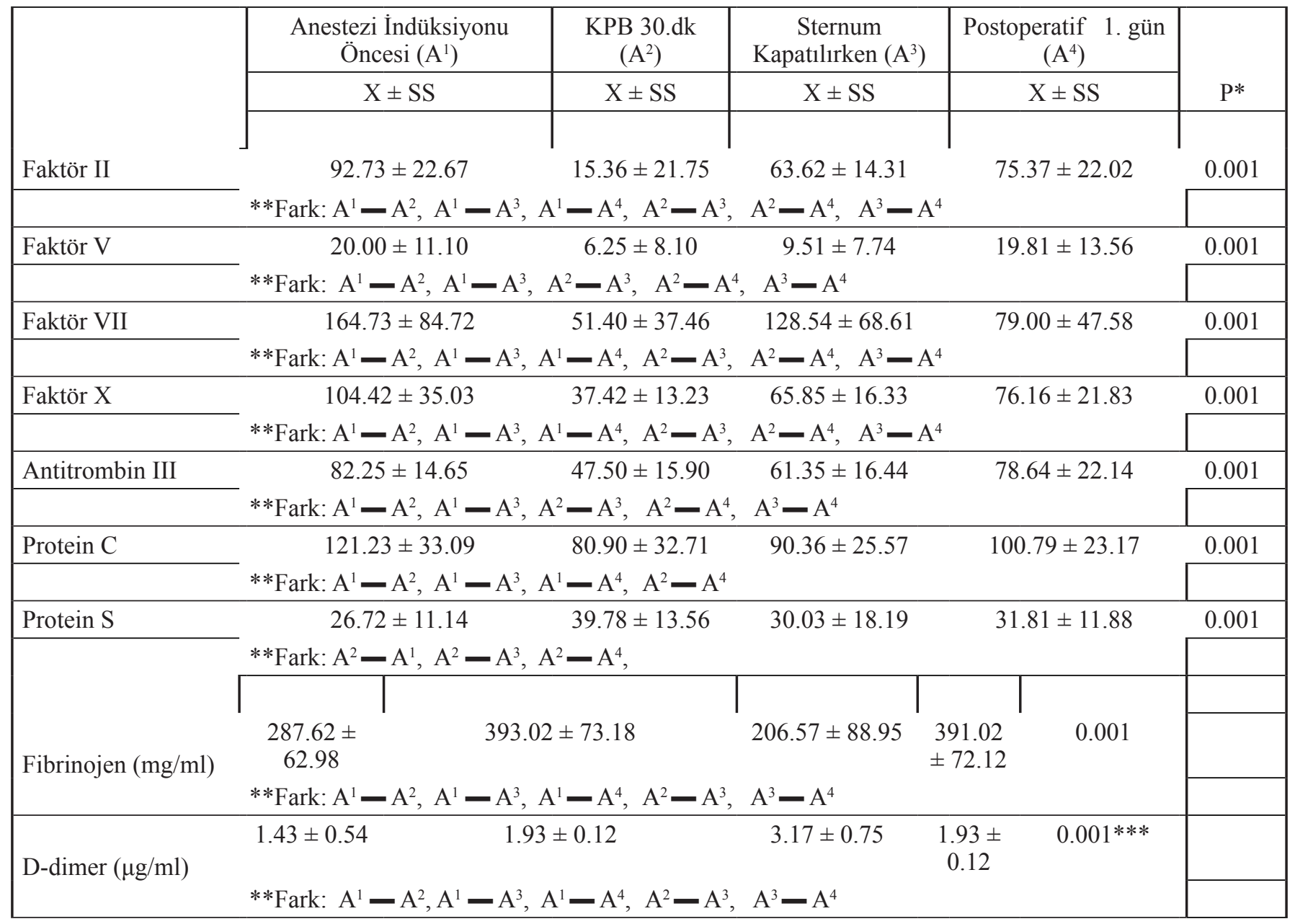

KPB: Kardiyo Pulmoner Baypass, $\mathbf{X} \pm$ SS: Ortalama \pm standart sapma.

${ }^{\star}$ Repeated Measures ANOVA testi uygulanmıştır.

${ }^{* *}$ Farklılığın hangi gruptan kaynaklandığını bulmak için Bonferroni testi kullanılmıştır.

${ }^{* * *}$ Freidman testi uygulanmıştır.

alınan hastalar çalışmaya dahil edilmedi.

Çalışmaya dahil edilen hastalarda; cinsiyet, yaş, kardiyopulmoner bypass süresi, kross klemp süresi, yoğun bakımdaki drenaj miktarı, kullanılan kan ürünü miktarı, yoğun bakım ve postoperatif hastanede kalış süreleri kaydedildi. Yapılan tekrarlı ölçümlerde ameliyathanede anestezi indüksiyonu öncesi, KPB başladıktan yarım saat sonra, sternum kapatıldıktan sonra ve postoperatif 1 . gün faktör II, faktör V, faktör VII, faktör X, antitrombin- III, protein $\mathrm{C}$, protein $\mathrm{S}$, fibrinojen, d-dimer, aPTT, PT, INR, trombosit hemoglobin, hematokrit için kan örnekleri alınarak koagülasyon sistemi değerlendirildi. Aynı zamanda preoperatif ve postoperatif 1., 2. ve 3. gün üre, kreatinin, AST ve ALT değerleri ölçüldü.

Hastalar postoperatif dönemde nörokognitif fonksiyonlar açısından yakından takip edildi.

İstatistiksel Yöntem:

Elde edilen veriler SPSS 20.0 (Statistical packet for Social Sciences for Windows) paket programinda değerlendirildi. İstatistiki hesaplamalar için; sayı, yüzde, ortalama ve standart sapma $(\mathrm{X} \pm \mathrm{SS})$ şeklinde değerler gösterildi. Non-parametrik değişkenlerin karşılaştırılmasında tekrarlı ölçümlerde Fridman testi kullanıldı. Parametrik değişkenlerin karşılaştırılmasında tekrarlı ölçümlerde ise Repeated-measures ANOVA testi ve tekrarlı ölçümler içinde zamana göre anlamlıllı̆̆n hangi ölçümden kaynaklandığını tespit etmek için post hoc test olarak Bonferroni kullanıldı. İstatistik anlamlılık değeri olarak $\mathrm{p}<0.05$ alındı.

\section{BULGULAR}

Tüm hastaların demografik, klinik ve cerrahi özellikleri Tablo 1'de verilmiştir. Araştırmaya dahil edilen hastaların \% 54.8'i kadın, \% 45.2'si erkek olup, yaş ortalaması $57.33 \pm 14.14$ idi. Ortalama KPB süresi $78.04 \pm 31.85 \mathrm{dk}$, kross klemp süresi $44.30 \pm 23.87 \mathrm{dk}$, drenaj miktarı $465.47 \pm 238.00 \mathrm{ml}$, yoğun bakım kalış süresi $2.66 \pm 1.09$ gün, hastanede kalış süresi $6.83 \pm 1.59$ idi. Kullanılan kan ürünlerine bakıldığında hastaların ortalama $3.88 \pm 2.76$ ünite taze donmuş plazma ve 2.52 \pm 1.65 ünite eritrosit süspansiyonu kullandığı görüldü (Tablo 1).

Hastaların anestezi indüksiyonu öncesi, KPB esnasında., sternum kapatilırken ve postoperatif 1 . 
Tablo 3: Çalışmaya alınan hastaların koagülasyon, hemotokrit ve hemoglobin parametreleri

\begin{tabular}{|c|c|c|c|c|c|}
\hline & $\begin{array}{c}\text { Anestezi } \\
\text { İndüksiyonu } \\
\text { Öncesi }\left(\mathbf{A}^{1}\right) \\
\end{array}$ & KPB 30.dk $\left(\mathbf{A}^{2}\right)$ & $\begin{array}{c}\text { Sternum } \\
\text { Kapatılırken } \\
\left(\mathbf{A}^{3}\right) \\
\end{array}$ & $\begin{array}{l}\text { Postoperatif 1. gün } \\
\qquad\left(\mathrm{A}^{4}\right)\end{array}$ & \multirow{4}{*}{$\frac{\mathrm{P}^{*}}{0.001}$} \\
\hline & $\mathrm{X} \pm \mathrm{SS}$ & $\mathrm{X} \pm \mathrm{SS}$ & $\mathrm{X} \pm \mathrm{SS}$ & $\mathrm{X} \pm \mathrm{SS}$ & \\
\hline \multirow{2}{*}{ aPTT (sn) } & $30.51 \pm 4.16$ & $44.36 \pm 16.30$ & \multirow[t]{2}{*}{$31.73 \pm 6.79$} & \multirow[t]{2}{*}{$30.17 \pm 3.39$} & \\
\hline & \multicolumn{2}{|c|}{$* *$ Fark: $\mathrm{A}^{2}-\mathrm{A}^{1}, \mathrm{~A}^{2}-\mathrm{A}^{3}, \mathrm{~A}^{2}-\mathrm{A}^{4}$} & & & \\
\hline \multirow{2}{*}{ PT } & $13.79 \pm 1.40$ & $15.91 \pm 1.38$ & $17.12 \pm 2.23$ & $14.75 \pm 1.77$ & 0.001 \\
\hline & \multicolumn{4}{|c|}{${ }^{* *}$ Fark: $\mathrm{A}^{1}-\mathrm{A}^{2}, \mathrm{~A}^{1}-\mathrm{A}^{3}, \mathrm{~A}^{1}-\mathrm{A}^{4}, \mathrm{~A}^{2}-\mathrm{A}^{3}, \mathrm{~A}^{2}-\mathrm{A}^{4}, \mathrm{~A}^{3}-\mathrm{A}^{4}$} & \\
\hline \multirow{2}{*}{ INR } & $1.15 \pm 0.12$ & $1.50 \pm 0.20$ & \multirow{2}{*}{$1.43 \pm 0.18$} & \multirow[t]{2}{*}{$1.26 \pm 0.24$} & \multirow[t]{2}{*}{0.001} \\
\hline & $* *$ Fark: $\mathrm{A}^{1}-\mathrm{A}$ & $\mathrm{A}^{1}-\mathrm{A}^{3}, \mathrm{~A}^{1}-\mathrm{A}^{4}$ & & & \\
\hline \multirow{2}{*}{ PLT $\left(\mathbf{m m}^{3}\right)$} & $225.30 \pm 12.17$ & $161.28 \pm 8.85$ & $180.45 \pm 7.07$ & \multirow[t]{2}{*}{$209.80 \pm 9.88$} & \multirow[t]{2}{*}{0.001} \\
\hline & $* *$ Fark: $\mathrm{A}^{1}-\mathrm{A}^{2}$ & $\mathrm{~A}^{1}-\mathrm{A}^{3}, \mathrm{~A}^{2}-\mathrm{A}^{3}$ & $\mathrm{~A}^{2}-\mathrm{A}^{4}, \mathrm{~A}^{3}$ & & \\
\hline \multirow{2}{*}{ Hematokrit $(\%)$} & $36.95 \pm 5.28$ & $25.36 \pm 4.92$ & \multirow{2}{*}{$\begin{array}{r}28.05 \pm 4.22 \\
\mathrm{~A}^{2}-\mathrm{A}^{3}, \mathrm{~A}^{2}-\end{array}$} & $31.43 \pm 4.00$ & \multirow[t]{2}{*}{0.001} \\
\hline & $* *$ Fark: $\mathrm{A}^{1}-\mathrm{A}^{2}$ & $A^{1}-A^{3}, A^{1}-A^{4}$ & & $A^{4}, A^{3}-A^{4}$ & \\
\hline \multirow{2}{*}{$\begin{array}{l}\text { Hemoglobin (g/ } \\
\text { dL) }\end{array}$} & $12.32 \pm 1.81$ & $8.26 \pm 1.53$ & \multirow{2}{*}{$\begin{array}{r}9.37 \pm 1.46 \\
\mathrm{~A}^{2}-\mathrm{A}^{3}, \quad \mathrm{~A}^{2}\end{array}$} & $10.27 \pm 1.19$ & \multirow[t]{2}{*}{0.001} \\
\hline & \multicolumn{3}{|c|}{${ }^{* * \text { Fark: }} \mathrm{A}^{1}-\mathrm{A}^{2}, \mathrm{~A}^{1}-\mathrm{A}^{3}, \mathrm{~A}^{1}-\mathrm{A}^{4}, \mathrm{~A}^{2}-\mathrm{A}^{3}, \mathrm{~A}^{2}-\mathrm{A}^{4}, \mathrm{~A}^{3}-\mathrm{A}^{4}$} & & \\
\hline
\end{tabular}

KPB: Kardiyo Pulmoner Baypass, $\mathbf{X} \pm$ SS: Ortalama \pm standart sapma,

${ }^{*}$ Repeated Measures ANOVA testi uygulanmıştır.

**Farklılığın hangi gruptan kaynaklandığını bulmak için Bonferroni testi kullanılmıştır.

*** Freidman testi uygulanmıştır. aPTT:Aktive Parsiyel Tromboplastin Zamanı, PLT:Trombosit, PTZ/INR:Protro

gün bakılan koagülasyon parametrelerinin değerleri Tablo 2'de verilmiştir. Faktör II, faktör V, antitrombin III ve protein $\mathrm{C}$ değerleri $\mathrm{KPB}$ esnasinda preoperatif değerlerine göre anlamlı olarak düşmekte, daha sonra yavaş yavaş yükselerek postoperatif 1. gün preoperatif değerlerine yaklaşmaktaydı. Faktör VII ve X düzeyleri de KPB esnasında preopereatif değerlerine göre çok fazla düşmekte ve KPB sonlandıktan sonra yavaş yavaş yükselmekteydi. Ancak postopertif 1. gün bile preoperatif değerine göre anlamlı olarak düşük seyretmekteydi.

Protein S değerleri ise KPB esnasında postoperatif düzeylerine göre anlamlı olarak yükselmekte, daha sonra yavaş yavaş bazal değerlerine doğru düşmekteydi. Fibrinojen düzey ölçümlerinde ise düzensizlik mevcuttu. KPB esnasında preoperatif değerine göre anlamlı olarak yükselmekte, KPB sonlandıktan sonraki değerleri başlangıç seviyesine göre daha da düşmekte ve postoperatif 1 . günde $\mathrm{KPB}$ esnasındaki değerlerine ulaşmaktaydı.

Asıl önemlisi D-dimer düzeyleri KPB esnasında preoperatif değerine göre istatistiksel olarak anlamlı olmasa bile yükselmekte, bu yükseliş KPB bittikten sonra istatistiksel olarak anlamlı olacak şekilde maksimuma ulaşmakta, postoperatif 1. günde düşmeye başlamaktaydı. Buna rağmen postoperatif 1 . gündeki düzeyleri preoperatif düzeylerine göre anlamlı olarak yüksekti.

Koagulasyon parametrelerinin farklı zaman aralıklarındaki ölçümleri Tablo 2'de detaylı olarak verilmiştir.

Hastaların aPTT değerleri KPB esnasında diğer ölçümlerden anlamlı olarak yüksek bulunurken INR değerleri KPB esnasında ve KPB sonrasında preoperatif ve postoperatif 1 . gün değerlerine göre anlamlı olarak yüksekti.

Hemoglobin ve hematokrit değerleri ve trombosit sayılarıKPBesnasındapreoperatifdeğerlerinegöreanlamlı olarak düşmekte, daha sonra yavaş yavaş yükselmekteydi. Ancak postoperatif 1 . günde preoperatif değerlerine göre hala düşük seyretmekteydi ve tüm zamanlarda yapılan ölçümler istatistiksel olarak birbirinden farklıydı. Tüm bu parametrelerle ilgili ayrıntılı bilgi Tablo 3'de verilmiştir.

Araştırmaya dahil edilen hastaların preoperatif, postoperatif 1., 2. ve 3 . günlerde bakılan böbrek ve karaciğer fonksiyon testlerinin laboratuvar bulguları Tablo 4'de verilmiştir.

Üre değerleri ölçüm zamanına göre doğrusal olarak yükselmiştir. Postoperatif 1. ve 2. gün değerleri hariç olmak üzere bütün değerler istatistiksel olarak birbirlerinden farklıydı. Kreatinin değerleri de operasyon sonrasında preoperatif değerine göre anlamlı olarak yükselmekte, sonra düşmekte ve postoperatif 3 . gün bazal değerlerine ulaşmaktaydı.

AST ve ALT değerleri de postoperatif 1. günde preoperatif değerlerine göre anlamlı olarak yükselmekte, ancak postoperatif 2. günde ALT değeri normal seviyeye dönerken AST değerleri 3. günde istatistiksel farklılık olmasa bile preoperatif değerinden yüksek seyretmekteydi.

\section{TARTIŞMA}

Açık kalp ameliyatlarından sonra meydana gelen organ fonksiyon bozukluklarının uzun zamandır 
Tablo 4: Çalışmaya alınan hastaların BFT, KCFT, hemogram ve PLT parametreleri

\begin{tabular}{|c|c|c|c|c|c|}
\hline & $\begin{array}{r}\text { Preoperatif } \\
\qquad\left(\mathrm{A}^{1}\right)\end{array}$ & $\begin{array}{l}\text { Postoperatif } \\
\text { 1. gün } \\
\qquad\left(\mathrm{A}^{2}\right)\end{array}$ & $\begin{array}{l}\text { Postoperatif } \\
\text { 2. gün } \\
\qquad\left(A^{3}\right)\end{array}$ & $\begin{array}{c}\text { Postoperatif } \\
\text { 3. gün } \\
\left(\mathbf{A}^{4}\right) \\
\end{array}$ & \\
\hline & $\mathrm{X} \pm \mathrm{SS}$ & $\mathrm{X} \pm \mathrm{SS}$ & $\mathrm{X} \pm \mathrm{SS}$ & $\mathrm{X} \pm \mathrm{S} \mathrm{S}$ & $\mathbf{P}$ \\
\hline \multirow{2}{*}{ Üre } & $15.78 \pm 4.08$ & $22.47 \pm 8.15$ & $27.28 \pm 12.60$ & $28.98 \pm 16.28$ & $0.001^{*}$ \\
\hline & \multicolumn{5}{|c|}{ Fark: $\mathrm{A}^{1}-\mathrm{A}^{2}, \mathrm{~A}^{1}-\mathrm{A}^{3}, \mathrm{~A}^{1}-\mathrm{A}^{4}, \mathrm{~A}^{2}-\mathrm{A}^{3}, \mathrm{~A}^{2}-\mathrm{A}^{4}$} \\
\hline \multirow{2}{*}{ Kreatin } & $0.89 \pm 0.20$ & $1.13 \pm 0.35$ & $1.19 \pm 0.37$ & $1.13 \pm 0.72$ & $0.001 *$ \\
\hline & \multicolumn{5}{|c|}{ Fark: $\mathrm{A}^{1}-\mathrm{A}^{2}, \mathrm{~A}^{1}-\mathrm{A}^{3}, \mathrm{~A}^{1}-\mathrm{A}^{4}, \mathrm{~A}^{2}-\mathrm{A}^{4}$} \\
\hline \multirow{2}{*}{ AST } & $24.69 \pm 7.73$ & $58.90 \pm 25.21$ & $49.16 \pm 29.20$ & $38.45 \pm 20.89$ & $0.001^{*}$ \\
\hline & \multicolumn{5}{|c|}{ Fark: $\mathrm{A}^{1}-\mathrm{A}^{2}, \mathrm{~A}^{1}-\mathrm{A}^{3}, \mathrm{~A}^{2}-\mathrm{A}^{3}, \mathrm{~A}^{2}-\mathrm{A}^{4}, \mathrm{~A}^{3}-\mathrm{A}^{4}$} \\
\hline \multirow{2}{*}{ ALT } & $23.90 \pm 10.67$ & $32.14 \pm 20.16$ & $24.85 \pm 15.88$ & $17.33 \pm 12.89$ & $0.001 *$ \\
\hline & \multicolumn{5}{|c|}{ Fark: $\mathrm{A}^{1}-\mathrm{A}^{2}, \mathrm{~A}^{1}-\mathrm{A}^{4}, \mathrm{~A}^{2}-\mathrm{A}^{3}, \mathrm{~A}^{2}-\mathrm{A}^{4}, \mathrm{~A}^{3}-\mathrm{A}^{4}$} \\
\hline
\end{tabular}

$\mathbf{X} \pm$ SS: Ortalama \pm standart sapma,

* Freidman testi uygulanmıştır.

${ }^{* *}$ Repeated Measures ANOVA testi uygulanmıştır. Farklılığın hangi gruptan kaynaklandığını bulmak için Bonferroni testi kullanılmıştır. AST:Aspartat aminotransferaz enzimi, ALT:Alanin aminotransferaz, PLT:Trombosit,

bilinen sebeplerinden biri, mikroembolilerdir. 40 mikronun altındaki emboliler vücudun çeşitli yerlerinde kalınlığı 8-10 mikron olan damarları tıkayarak hücre ölümüne sebep olur. Yaygın hücre nekrozu ile kapiller permeabilitede artı̧̧intertisyel ödeme sebep olur. Sistemik venöz basınç artarken hemodilüsyon ile kolloid ozmotik basınç düşer. KPB zamanına da bağlı olarak interstisyel sıvı miktarı giderek artar. Bu dönemde multipl emboliler kalp, akciğer, böbrek, santral sinir sistemi, pankreas ve karaciğer başta olmak üzere tüm organlarda fonksiyonel bozukluklara sebep olur. Bu çalışmada, kardiyopulmoner bypass esnasında antikoagülan kullanımının mikrotrombüs oluşumunu engelleyip engellemediğini incelenmiştir.

Normal çalışan bir koagülasyon sistemi sağlıklı yaşam için vazgeçilmez bir olgudur. Öyle ki, bir savunma sistemi olarak da adlandırılmaktadır. Herhangi bir sebeple ortaya çıkan kanamanın durdurulması kadar, lezyon yerinde oluşan pıhtının temizlenmesi de önemlidir. Hemostaz, kanamayı durdurmak amacıyla pıhtı oluşumu ve lizisinin, patolojik pıhtılaşma oluşturmadan sistematik bir şekilde aktivasyonudur. Farklı bir ifade ile, dolaşım sistemindeki bütün sıvıların korunmasını sağlayan sistemdir. Bu sistemde vasküler faktörler, koagülasyon proteinleri ve trombositler gibi çok sayıda eleman rol almaktadır.

Vazoaktif maddelerin birçoğu tamamen KPB esnasında etkilenirken bir kısmı ise kısmen KPB esnasında etkilenmektedir. $\mathrm{Bu}$ maddeler ödem, miyokardiyal kontraktilitede azalma, vasküler resiztans değişikliklerine sebep olurlar. Koagulasyon yolunun aktivasyonu, kan hücrelerinin destrüksiyonu, çeşitli embolilerde vazoaktif madde salınımına neden olurlar. 40 mikronun altındaki emboliler vücudun çeşitli yerlerinde kalınlı̆̆ı 8-10 mikron olan damarları tıkayarak hücre ölümüne sebep olur. Yaygın hücre nekrozu ile kapiller permeabilitede KSU Medical Journal 2018;13(1) 1-6 artış intertisyel ödeme sebep olur. Sistemik venöz basınç artarken hemodilüsyon ile kolloid ozmotik basınç düşer. KPB zamaına da bağlı olarak interstisyel sıvı miktarı giderek artar. Bu dönem ve multipl emboliler kalp, akciğer, böbrek, santral sinir sistemi, pankreas ve karaciğer başta olmak üzere tüm organlarda fonksiyonel bozukluklara sebep olur. $\mathrm{Bu}$ disfonksiyonlar ise genellikle geçicidir. Ancak bazı olgularda KPB sonrası \% 60'a varan, 1 yıla dek uzayan ve ancak nörofizyolojik testlerle saptanabilen nörolojik defisitlerin varlığı ise diğer organ sistemleri için de bir fikir verebilir (3). Açık kalp ameliyatlarından sonra nörolojik ve nöropsikolojik komplikasyonların etyolojisi multifaktöryeldir. $\mathrm{Bu}$ faktörler, intraoperatif mikro veya makro emboliden meydana gelen hasar, anormal serebral perfüzyon, enflamatuar, nörohumoral cevaplar, premorbid hastalıklar ve yaşlılıktır. Sebep ne olursa olsun sonuç genellikle aynıdır: nöronal hipoksi ve iskemidir (4). İskemi KPB esnasında oluşan hipoperfüzyona mi, yoksa oluşan mikrotrombüslere mi bağlidır? Bu henüz kesin cevabı verilmiş bir soru değildir. Bu soruya bir cevap bulabilmek amacıyla biz bu çalışmayı planladık. Çalışmamızda hemoglobin, hematokrit, trombosit değerlerinin KPB esnasında bazal değerlerine göre düştügünü ve daha sonra yavaş yavaş normal değerlerine ulaştığını tespit ettik. Bu düşüş hemodilüsyona veya KPB esnasında kanın şekilli elemanlarını hasar görmesine bağlı bilinen bir durumdur. Yine aPTT ve INR değerleri KPB esnasında artmakta ve daha sonra bazal değerlerine doğru düşmekteydiler.

Koagulasyon parametrelerine bakıldığında koagulasyon kaskadında rol oynayan faktör II, V, VII ve X değerleri KPB esnasında düşmekte ve sonrasında yavaş yavaş yükselmekteydi. Harker ve ark.ları tüm koagülasyon faktörlerinin KPB esnasında azaldığını ve KPB'tan sonraki 12 saat içinde normal seviyelerine geldiğini ifade etmişlerdir (5). KPB sonrası cerrahi 
olmayan kanama heparin, trombosit ve fibrinolizis ile ilişskilidir. Kaogulasyon faktör eksikliği sık görülmeyen bir nedendir. KPB esnasında dilüsyon ve tüketim sebebiyle hafif bir şekilde seviyesi düşen faktör 5 sıklıkla önemli bir kanama problemine neden olmaz (6). Çalışmamızda antitrombin III düzeylerinde de durum koagulasyon faktörlerinde olduğu gibi KPB esnasında azalma gözlendi ve $\mathrm{KPB}$ sonrasında yavaş yavaş normal değerlerine doğru yükselmeye başladı. Bu durumun belki yine de hemodilüsyona bağlı olduğu düşünülebilirdi. Ayrıca heparin, F12a, kallikrein, aktive kompleman, plazmin gibi proteazlar ile faktör 9a, faktör 10a, faktör 11a gibi prhtılaşma faktörlerini inhibe eden ve doğal bir plazma proteiniolan antitrombini aktive ederek antikoagulasyonu sağlar (7). KPB sırasında heparine bağlı olarak AT III düzeyi azalırken KPB’nin sonlandırılmasına doğru yapılan protamine bağlı olarakta AT- III seviyesi tekrar artar (8). Bu durumda KPB esnasinda AT III seviyelerindeki düşüşün heparine bağlı olduğu düşünülebilir. Ancak fibrin yıkım ürünlerini gösteren D-dimer seviyeleri KPB esnasında yükselmekte bu yükseliş KPB sonrasında da devam etmekte, postoperatif 1 . günde KPB esnasındaki seviyesine inmekteydi. Vücutta bir trombüs oluştuğunda fibrinojenden fibrin oluşmakta ve daha sonraki süreçte bu trombüs lizise uğramakta ve fibrin yıkım ürünleri oluşmaktadır. D-dimerin yükselmesi vücutta bir trombüs oluştuğunun ve bu trombüsün parçalanmaya başladığının bir göstergesidir. D-dimer, fibrinolitik aktivasyonu belirlemek için en spesifik metottur $(9,10)$. Bu durumda her ne kadar fibrinojen seviyeleri dalgalı seyretse de diğer koagulasyon faktörlerinin seviyesinin düşmesinin bu faktörlerin tüketilmesine bağlı olduğunu düşünülebilir.

Çalışmamızda KPB esnasında karaciğer ve böbrek fonksiyon testlerinde minimal bir bozulma tespit ettik. $\mathrm{Bu} \mathrm{KPB}$ esnasında oluşan hemodilüsyona ve geçici hipoksiye de bağlı olabilir. Bu tür fonksiyon bozukluğunu trombüs oluşumuna bağlamak doğru olmayabilir. Yine nörokognitif fonksiyonlarda herhangi bir bozulma tespit etmedik.

Sonuç olarak koagulasyon faktörlerinin seviyesinde düşme ve D-dimer seviyesinde yükselmeye bağlı olarak KPB esnasında antikoagulan kullanılmasına rağmen trombüs gelişiminin tam olarak engellenmediğini düşünmekteyiz. Ancak bu olay klinik olarak önemli olmayıp herhangi önemli bir organ fonksiyonuna sebep olmamaktadır.

\section{KAYNAKLAR}

1. Tanaka K, Takao M, Yada I, Yuasa H, Kusagawa M, Deguchi K. Alterations in coagulation and fibrinolysis associated with cardiopulmonary bypass during open heart surgery. J Cardiothorac Anesth. 1989; 3: 181-8.

2. Dietrich W. Reducing thrombin formation during cardiopulmonary bypass: is there a benefit of the additional anticoagulant action of aprotinin? J Cardiovasc Pharmacol. 1996; 27 Suppl 1: S50-7

3. Videm V, Svennevig JL, Fosse E, Semb G, Osterud A, Mollnes TE. Reduced complement activation with heparin-coated oxygenator and tubings in coronary bypass operations. J Thorac Cardiovasc Surg 1992; 103: 806-13.

4. Bevilacqua MP, Pober JS, Majeau GR, Fiers W, Cotran RS, Gimbrone MA. Recombinant tumor necrosis factor induces procoagulant activity in cultured human vascular endothelium: characterization and comparison with the action of interleukin 1. Proc Natl Acad Sci 1986; 83: 4533-7.

5. Harker LA, Malpass TW, Branson HE, Hessel EA, Slichter SJ. Mechanism of abnormal bleeding in patients undergoing cardiopulmonary bypass: Acquired transient platelet dysfunction associated with selective alpha granule release. Blood 1980; 56: 824-34.

6. Phillis JW. Adenosine in the control of the cerebral circulation. Cerebrovasc Brain Metab Rev, 1989;1: 26-54.

7. Somson S, Shore-Lesserson L. Platelet functeon and cardiopulmonary bypass. Semin Cardiothorac Vasc Anesth 2001; 5: 273-81.

8. Hashimoto K, Yamagishi M, Sasaki T, Nakano M, Kurosawa H. Heparin and antithrombin III levels during cardiopulmonary bypass: correlation with subclinical plasma coagulation. Ann Thorac Surg., 1994; 58: 799-804

9. Woodman RC, Harker LA. Bleeding complications associated with cardiopulmonary bypass. Blood 1990; 76: 1680-97.

10. Matsuo T, Kobayashi H, Kario K, Suzuki S. Fibrin $\mathrm{D}$ dimer in thrombogenic disorders. Semin Thromb Hemos 2000; 26: 101-7. 